Original paper

\title{
Phlogopite/matrix, clinopyroxene/matrix and clinopyroxene/ /phlogopite trace-element partitioning in a calc-alkaline lamprophyre: new constrains from the Křižanovice minette dyke (Bohemian Massif)
}

\author{
Lukáš KRMÍČEK1*, Michaela HALAVÍNOVÁ1, Rolf L. ROMER², Michaela VAŠINOVÁ GALIOVÁ ${ }^{3,4}$, \\ Tomáš VACULOVIČ ${ }^{3,4}$
}

\author{
${ }^{1}$ Brno University of Technology, Faculty of Civil Engineering, Veveři 95, 60200 Brno, Czech Republic; l.krmicek@gmail.com \\ 2 Deutsches GeoForschungsZentrum (GFZ), Telegrafenberg, 14473 Potsdam, Germany \\ ${ }^{3}$ Masaryk University, Faculty of Science, Department of Chemistry, Kotlářská 2, 61137 Brno, Czech Republic \\ ${ }^{4}$ Masaryk University, Central European Institute of Technology, Kamenice 5, 62500 Brno, Czech Republic \\ * Corresponding author
}

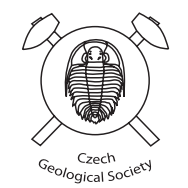

\begin{abstract}
Mineral/matrix and mineral/mineral partition coefficients were determined for clinopyroxene and phlogopite phenocrysts and their very fine-grained (chilled) groundmass from a Variscan calc-alkaline (agpaitic index $=0.6$ ) lamprophyre dyke of minette composition from the Bohemian Massif (Křižanovice, Teplá-Barrandian Unit). This dyke is characterized by high $\mathrm{MgO}(8.9$ wt. \%; $\mathrm{Mg}$-number $=69)$ at intermediate $\mathrm{SiO}_{2}$ content $(53 \mathrm{wt}$. \%). The partition coefficients $(D)$ between clinopyroxene and matrix were determined for 23 elements by laser ablation-inductively coupled plasma-mass spectrometry. Calculated clinopyroxene/matrix $D$ values are very low, except for heavy rare earth elements (HREE) that range between 0.9 and 1.1. This suggests that HREE can be concentrated in clinopyroxene during crystallization from lamprophyre melt. In phlogopite, only 15 elements had contents above their respective detection limits. Phlogopite/matrix partition coefficients are on average higher than $1\left(D_{\mathrm{Ba}}=1.1, D_{\mathrm{Rb}}=1.7 D_{\mathrm{Ti}}=1.5\right)$ and extremely low $(\leq 0.02)$ for light rare earth elements (LREE). On the other hand, phlogopitermatrix $D$ values for the majority of HREE could not be determined. Taken together, during simultaneous crystallization of clinopyroxene and phlogopite phenocrysts, Th, Zr, Hf, Y and LREE are preferentially partitioned into clinopyroxene and $\mathrm{Ba}$ with $\mathrm{Rb}$ and $\mathrm{Ti}$ into phlogopite.
\end{abstract}

Keywords: calc-alkaline lamprophyres, mineralogy, partition coefficients, Bohemian Massif

Received: 31 May 2013; accepted: 7 February 2014; handling editor: F. V. Holub

\section{Introduction}

Representative mineral/melt partition coefficients are necessary for geochemical modeling of magmatic systems. Element partitioning between minerals and melt strongly depends, apart from pressure and temperature, also on the type of melt and changes with a higher degree of melt fractionation, i.e. lower $\mathrm{MgO}$ and higher $\mathrm{SiO}_{2}$ contents (e.g. Blundy and Wood 2003; Foley et al. 2013).

Lamprophyre melts are characterized by (i) high $\mathrm{MgO}$ with variable $\mathrm{SiO}_{2}$, reflecting their enriched or depleted mantle source and the degree of partial melting, and (ii) high contents of network-modifying elements, in particular $\mathrm{K}, \mathrm{Na}$, and $\mathrm{P}$, which may change polymerization, coordination, and thus ultimately element partitioning. Because of the different content of network-modifying elements, partition coefficients determined on MORBrelated melts (e.g. Klimm et al. 2008 and references therein) or MARID-related (mica-K-amphibole-rutileilmenite-diopside) mantle-derived rocks such as lamproites (Schmidt et al. 1999; Foley and Jenner 2004) may not be applicable to lamprophyres or may vary between different types of lamprophyre. The effect of melt polymerization on trace-element partitioning was recently highlighted by Simon et al. (2013).

Trace-element partitioning between mafic minerals and mantle-derived melt of lamprophyric composition has been discussed in only a limited number of papers. Foley et al. (1996) determined trace-element partition coefficients for clinopyroxene and phlogopite in an alkaline dyke from Budgell Harbour in north-central Newfoundland using laser ablation inductively coupled plasma mass spectrometry (LA-ICP-MS). This moderately evolved dyke with $\mathrm{Mg}$-number $[\mathrm{mg} \#=$ molar $100 \times \mathrm{MgO} /(\mathrm{MgO}$ $+\mathrm{FeOt})]$ of 60 was classified as monchiquite. In addition, Plá Cid et al. (2005) applied secondary ion mass spectrometry (SIMS) to determine trace-elements partitioning between clinopyroxene and mica from mafic enclaves containing K-clinopyroxene and pyrope-rich garnet in the Piquiri Syenite Massif, southernmost Brazil. These variably evolved very high-pressure (3-5 GPa) mafic enclaves of intermediate composition $(\mathrm{mg} \#=62-66)$ 


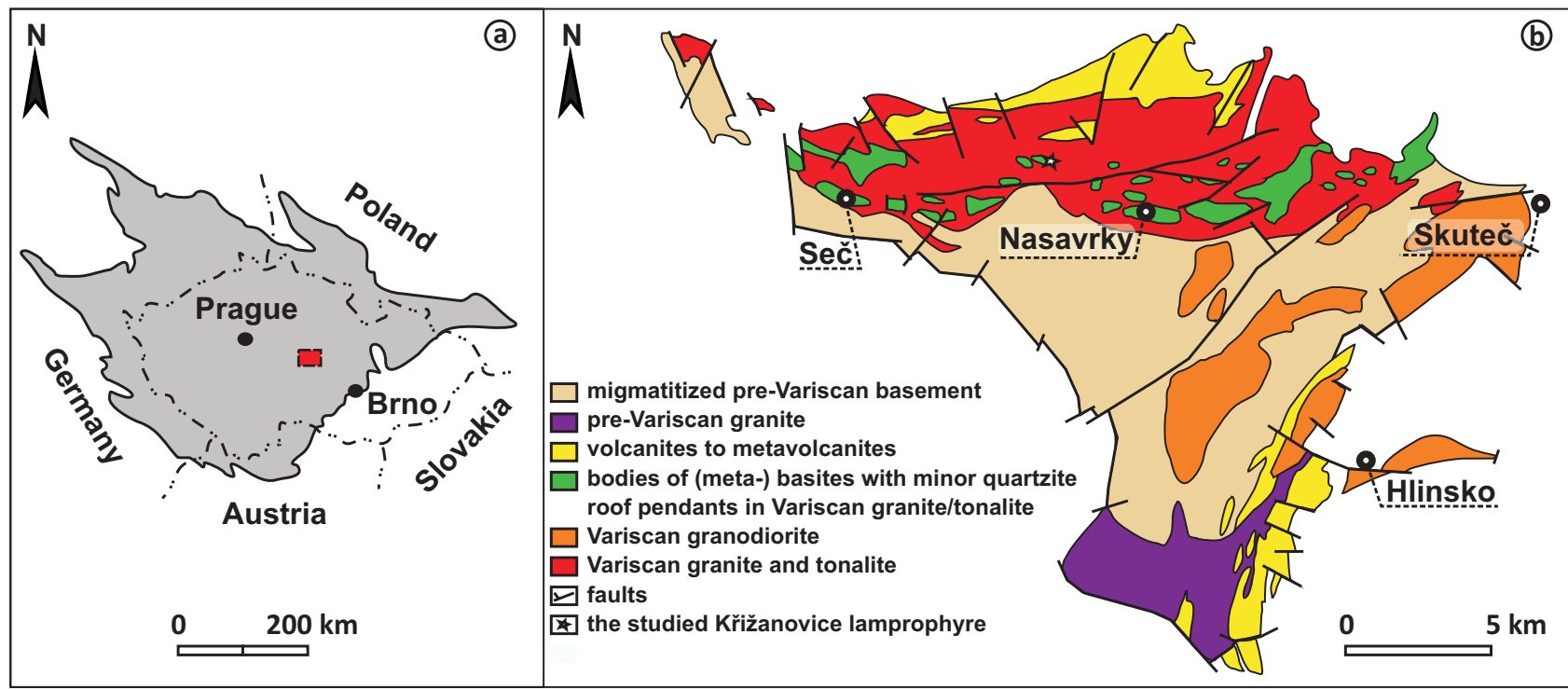

Fig. 1 Location of the studied area in the Bohemian Massif (a) with the geological sketch-map of the Železné hory composite Pluton containing various local igneous types (b). Modified from Hájek et al. (1997) and Klomínský et al. (2010).

resemble calc-alkaline lamprophyres - minettes, but have a high agpaitic/peralkalinity index $\left[\operatorname{molar}\left(\mathrm{K}_{2} \mathrm{O}+\mathrm{Na}_{2} \mathrm{O}\right) /\right.$ $\mathrm{Al}_{2} \mathrm{O}_{3}$ ] of $0.98-1.03$ that makes them to straddle the boundary between alkaline and peralkaline rocks (Shand 1943). Furthermore, the trace-element compositions of the enclaves are quite similar to those of silica-rich lamproites (Plá Cid et al. 2005).

The aim of this study is to present data on the phlogopite/matrix, clinopyroxene/matrix, and clinopyroxene/ phlogopite trace-element partitioning in a calc-alkaline lamprophyric system with mg\# close to a value of mantle-derived melts. The investigation was performed on a fresh minette dyke from the Bohemian Massif, a classical terrain from which lamprophyres were described first (Gümbel 1874). The studied dyke is little affected by fractionation and contains compositionally homogenous phenocrysts of mafic mica and clinopyroxene showing textures of coeval crystallization and - along chilled dyke margins - surrounded by aphanitic matrix.

\section{Geological setting}

The Křižanovice dyke belongs to a wider dyke swarm exposed between the villages Křižanovice and Samařov - intruding a mylonitised zone close to the exocontact of a Variscan biotite tonalite of the Železné hory (Nasavrky) composite Pluton (e.g. Hájek et al. 1997; Fig. 1). Lamprophyric dykes of the Železné hory Mts. were first studied by Němec (1991) and later by Krmíček et al. (2008) and Krmíček (2011). The dykes correspond both to typical calc-alkaline lamprophyres (minettes-kersantites) and to transitional types of lamproitic affinity, min- eralogically corresponding to cocites sensu Rock (1991). Cocites from the Bohemian Massif are characterized - in comparison with typical lamprophyres and lamproites by a remarkable negative Eu anomaly, an extremely high positive $\mathrm{Pb}$ anomaly, and an unusually high $\mathrm{Sm} / \mathrm{La}$ ratio (Krmíček 2011; Krmíček and Romer 2013). These rocks share many compositional characteristics with so-called lamproites (in fact rocks of lamproitic affinity) from the Alpine-Himalayan orogen (e.g. Tommasini et al. 2011; Fritschle et al. 2013; Prelević et al. 2013 and references therein). They do not, however, fit the lamproite classification criteria of Mitchell and Bergman (1991).

Dykes of the Krrižanovice-Samařov zone belong to the calc-alkaline lamprophyres. The freshest material was available from shafts and boreholes drilled in the 1980's for barite-sphalerite prospection. The dykes strike approximately $\mathrm{E}-\mathrm{W}$, dip steeply to the $\mathrm{S}$ and are up to $1 \mathrm{~m}$ thick. The Křžžnovice dyke exhibits a simple zonation with an aphanitic (chilled) margin at the contact with its sericite quartzite host. The dyke was uncovered during the construction of a prospection shaft $\left(15.7512678^{\circ} \mathrm{E}\right.$, $49.8579533^{\circ} \mathrm{N}$ ) and samples taken by D. Němec were deposited in the Moravian Museum in Brno.

\section{Analytical methods}

Thin sections of the Křižanovice dyke were studied using conventional optical and cathodoluminescence microscopy. The latter was carried out at Masaryk University using a microscope-equipped hot cathode HC2-LM (Simon Neuser, Bochum) with an accelerating voltage of $14 \mathrm{kV}$ and beam density of $10 \mu \mathrm{A} / \mathrm{mm}^{2}$. 
Mineral analyses were performed at the Laboratory of Electron Microscopy and Microanalysis, jointly operated by the Masaryk University (Brno) and the Czech Geological Survey, using a CAMECA SX100 electron microprobe. It was operated at $15 \mathrm{keV}$ acceleration voltage and $10 \mathrm{nA}$ beam current. Mineral analyses were carried out with a $10 \mu \mathrm{m}$ wide beam, whereas the majorelement matrix composition was determined as average from analyses obtained with a defocused beam $100 \mu \mathrm{m}$ wide. The following standard materials were used for calibration: albite (Na), sanidine ( $\mathrm{Si}, \mathrm{K}$ and $\mathrm{Al}$ ), andradite $(\mathrm{Ca})$, almandine $(\mathrm{Fe}), \mathrm{MgAl}_{2} \mathrm{O}_{4}(\mathrm{Mg})$, benitoite $(\mathrm{Ba})$, spessartine $(\mathrm{Mn})$, titanite $(\mathrm{Ti})$, apatite $(\mathrm{P})$, gahnite $(\mathrm{Zn})$, chromite $(\mathrm{Cr}), \mathrm{V}(\mathrm{V}), \mathrm{Ni}(\mathrm{Ni})$, topaz $(\mathrm{F})$ and $\mathrm{NaCl}(\mathrm{Cl})$. Analyses were done using $\mathrm{K}_{\alpha}(\mathrm{Na}, \mathrm{Si}, \mathrm{K}, \mathrm{Al}, \mathrm{Ca}, \mathrm{Fe}, \mathrm{Mg}$, $\mathrm{Mn}, \mathrm{Ti}, \mathrm{P}, \mathrm{Zn}, \mathrm{Cr}, \mathrm{V}, \mathrm{Ni}, \mathrm{F}$ and $\mathrm{Cl}$ ) and $\mathrm{L}_{\beta}(\mathrm{Ba})$ lines. The raw data were reduced using the PAP matrix correction (Pouchou and Pichoir 1985). Mineral compositions and formulae are listed and discussed in atoms per formula units $(a p f u)$ and $\mathrm{X}_{\mathrm{Mg}}[\mathrm{Mg} /(\mathrm{Mg}+\mathrm{Fe})]$.

Trace-element contents in clinopyroxene, phlogopite and matrix were analysed by LA-ICP-MS in the Laboratory of Atomic Spectrochemistry, Department of Chemistry, Masaryk University. The equipment consists of a New Wave UP 213 laser ablation system and an Agilent 7500ce ICP-MS. The laser-ablation system consists of pulsed Nd:YAG laser operating at $213 \mathrm{~nm}$ with a pulse duration of $4.2 \mathrm{~ns}$ and a laser ablation cell - SuperCell $\left(33 \mathrm{~cm}^{3}\right)$. Calibration of LA-ICP-MS conditions was done using the glass reference material NIST SRM 612. The $\mathrm{SiO}_{2}$ values were used as an internal standard. Average $\mathrm{SiO}_{2}$ contents in the matrix are $53 \mathrm{wt} . \%$, which is fully compatible with the $\mathrm{SiO}_{2}$ content of the whole rock recalculated on a volatile-free basis. Whole-rock chemical analysis was carried out at the ACME Analytical Laboratories Ltd, Vancouver, Canada, using ICP-ES (major oxides, $\mathrm{Ba}, \mathrm{Ni}, \mathrm{Cu}, \mathrm{Pb}, \mathrm{Zn}$ ) and ICP-MS (Co, Cs, Hf, $\mathrm{Nb}, \mathrm{Rb}, \mathrm{Sr}, \mathrm{Ta}, \mathrm{Th}, \mathrm{U}, \mathrm{V}, \mathrm{Zr}, \mathrm{Y}$ and REE).

Laser ablation was performed with a $65 \mu \mathrm{m}$ wide laser beam, a $10 \mathrm{~Hz}$ repetition rate and fluence of $6 \mathrm{~J} \mathrm{~cm}^{-2}$. The various element concentrations were determined using the following masses and their typical detection limits: ${ }^{7} \mathrm{Li}(25 \mathrm{ppm}),{ }^{24} \mathrm{Mg}$ (4 ppm), ${ }^{28} \mathrm{Si}(1110 \mathrm{ppm})$, ${ }^{31} \mathrm{P}(449 \mathrm{ppm}),{ }^{42} \mathrm{Ca}(1680 \mathrm{ppm}),{ }^{45} \mathrm{Sc}(5 \mathrm{ppm}),{ }^{49} \mathrm{Ti}$ (30 ppm), ${ }^{51} \mathrm{~V}(2 \mathrm{ppm}),{ }^{52} \mathrm{Cr}(50 \mathrm{ppm}),{ }^{60} \mathrm{Ni}(7 \mathrm{ppm}),{ }^{85} \mathrm{Rb}$ (1 ppm), ${ }^{88} \mathrm{Sr}(0.5 \mathrm{ppm}),{ }^{89} \mathrm{Y}(0.5 \mathrm{ppm}),{ }^{90} \mathrm{Zr}(1 \mathrm{ppm}),{ }^{93} \mathrm{Nb}$ (2 ppm), ${ }^{133} \mathrm{Cs}(0.5 \mathrm{ppm}),{ }^{137} \mathrm{Ba}(2 \mathrm{ppm}),{ }^{139} \mathrm{La}(0.3 \mathrm{ppm})$, ${ }^{140} \mathrm{Ce}(0.1 \mathrm{ppm}),{ }^{141} \mathrm{Pr}(0.1 \mathrm{ppm}),{ }^{146} \mathrm{Nd}(0.5 \mathrm{ppm})$, ${ }^{147} \mathrm{Sm}(0.5 \mathrm{ppm}),{ }^{153} \mathrm{Eu}(0.2 \mathrm{ppm}),{ }^{157} \mathrm{Gd}(0.2 \mathrm{ppm})$, ${ }^{159} \mathrm{~Tb}(0.1 \mathrm{ppm}),{ }^{163} \mathrm{Dy}(0.1 \mathrm{ppm}),{ }^{165} \mathrm{Ho}(0.1 \mathrm{ppm}),{ }^{166} \mathrm{Er}$ $(0.3 \mathrm{ppm}),{ }^{169} \mathrm{Tm}(0.1 \mathrm{ppm}),{ }^{172} \mathrm{Yb}(0.5 \mathrm{ppm}),{ }^{175} \mathrm{Lu}$ (0.1 ppm), ${ }^{178} \mathrm{Hf}(0.5 \mathrm{ppm}),{ }^{181} \mathrm{Ta}(1 \mathrm{ppm}),{ }^{206} \mathrm{~Pb}(2 \mathrm{ppm})$, ${ }^{232} \mathrm{Th}(0.5 \mathrm{ppm})$, and ${ }^{238} \mathrm{U}(0.5 \mathrm{ppm})$. Element contents above their respective detection limits were used to calculate Nernst partition coefficients from conjugated analytical spots of mineral/matrix pairs ( ${ }^{\text {mineral/matrix }} D_{\text {element }}$ ) and mineral/mineral pairs ( ${ }^{\text {mineral/mineral }} D_{\text {element }}$ ), respectively.

\section{Results}

\subsection{Petrography of the Křižanovice lamprophyre}

Following the nomenclature of calc-alkaline lamprophyres, also referred to as "true lamprophyres" (Krmíček 2011), "shoshonitic lamprophyres" (Rock 1991) or "potassic lamprophyres" (Scarrow et al. 2008 and discussion therein), the studied dyke corresponds to minette. The rock has a porphyritic (lamprophyric) texture with phenocrysts (up to $0.5 \mathrm{~mm})$ and microphenocrysts $(0.01-0.05 \mathrm{~mm})$ of phlogopite and diopside, without signs of disequilibrium textures. Phlogopite and diopside occur both as individual crystals and as glomeroporphyritic aggregates of euhedral to subhedral crystals with straight contacts (Fig. 2). Phlogopite and diopside do not show signs of resorption. K-feldspar with light blue luminescence displays pilotaxitic to (along chilled margins) aphanitic texture and is restricted to the groundmass where it predominates over albitised plagioclase microliths. Accessory minerals include common euhedral magnetite and less abundant needles of apatite, which are characterized by typical yellow-greenish luminescence and show no signs of growth under mixing conditions (e.g. Słaby and Götze 2004; Götze 2012).

\subsection{Whole-rock geochemical characteristics of the studied minette}

Whole-rock chemical data of the Křižanovice dyke are listed in Tab. 1. The dyke is characterized by a very

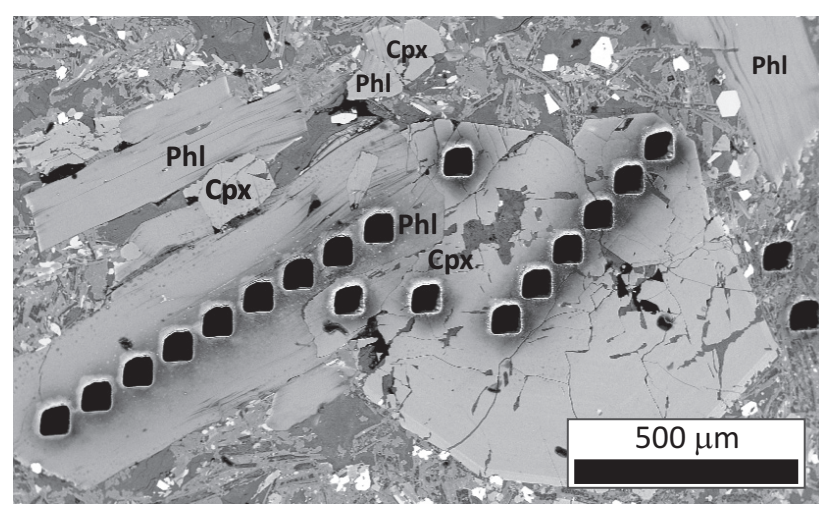

Fig. 2 Back-scattered electron image from the Křižanovice sample showing clinopyroxene (Cpx) and phlogopite (Phl) phenocrysts and microphenocrysts grown together in the form of euhedral to subhedral crystals. Analytical profiles (ablation craters) demonstrate no compositional zoning of the various minerals. 
Tab. 1 Whole-rock composition of the investigated calc-alkaline lamprophyre from Křižanovice (Krmíček 2011)

\begin{tabular}{lrlr}
\hline \multicolumn{4}{c}{ Major-element oxides (wt. \%) } \\
\hline $\mathrm{SiO}_{2}$ & 49.54 & $\mathrm{Na}_{2} \mathrm{O}$ & 1.72 \\
$\mathrm{TiO}_{2}$ & 0.97 & $\mathrm{~K}_{2} \mathrm{O}$ & 5.26 \\
$\mathrm{Al}_{2} \mathrm{O}_{3}$ & 14.22 & $\mathrm{P}_{2} \mathrm{O}_{5}$ & 0.74 \\
$\mathrm{Fe}_{2} \mathrm{O}_{3}{ }^{*}$ & 7.39 & $\mathrm{LOI}$ & 6.20 \\
$\mathrm{MnO}$ & 0.09 & $\mathrm{Total}$ & 99.25 \\
$\mathrm{MgO}$ & 8.24 & $(\mathrm{Na}+\mathrm{K}) / \mathrm{Al}$ & 0.60 \\
$\mathrm{CaO}$ & 4.88 & $\left.100 \mathrm{Mg} / \mathrm{Mg}+\mathrm{Fe}_{\text {tot }}\right)$ & 69 \\
\hline \multicolumn{4}{c}{$\mathrm{Trace}$ elements $(\mathrm{ppm})$} \\
$\mathrm{Sr}$ & 1049.0 & $\mathrm{Zn}$ & 520.0 \\
$\mathrm{Rb}$ & 59.4 & $\mathrm{Cu}$ & 29.7 \\
$\mathrm{Ba}$ & 2648 & $\mathrm{La}$ & 138.50 \\
$\mathrm{Cs}$ & 2.9 & $\mathrm{Ce}$ & 284.70 \\
$\mathrm{Th}$ & 24.4 & $\mathrm{Pr}$ & 36.23 \\
$\mathrm{U}$ & 4.9 & $\mathrm{Nd}$ & 138.10 \\
$\mathrm{Ta}$ & 0.6 & $\mathrm{Sm}$ & 19.32 \\
$\mathrm{Nb}$ & 12.2 & $\mathrm{Eu}$ & 5.43 \\
$\mathrm{Zr}$ & 289.6 & $\mathrm{Gd}$ & 15.01 \\
$\mathrm{Hf}$ & 7.5 & $\mathrm{~Tb}$ & 1.25 \\
$\mathrm{Y}$ & 26.7 & $\mathrm{Dy}$ & 5.50 \\
$\mathrm{~Pb}$ & 8.7 & $\mathrm{Ho}$ & 0.81 \\
$\mathrm{Co}$ & 26.1 & $\mathrm{Er}$ & 2.17 \\
$\mathrm{Ni}$ & 54.0 & $\mathrm{Tm}$ & 0.32 \\
$\mathrm{Cr}$ & 102.6 & $\mathrm{Yb}$ & 2.07 \\
$\mathrm{~V}$ & 133.0 & $\mathrm{Lu}$ & 0.28 \\
\hline & & & \\
& &
\end{tabular}

high $\mathrm{MgO}$ content (8.9 wt. \%; volatile-free basis) with respect to its intermediate $\mathrm{SiO}_{2}$ content (53 wt. \%). Its high mg\# of 69 is close to that of a primary melt in equilibrium with mantle rocks (e.g. Rock 1991). The dyke is also characterized by elevated contents of $\mathrm{K}_{2} \mathrm{O}$ (5.7 wt. \%) and $\mathrm{Al}_{2} \mathrm{O}_{3}(15.3$ wt. \%). The rock plots within the shoshonite field of the $\mathrm{K}_{2} \mathrm{O}$ versus $\mathrm{SiO}_{2}$ diagram (Peccerillo and Taylor 1976), however, it is neither shoshonitic (see Scarrow et al. 2008) nor ultrapotassic sensu stricto, as its molar $\mathrm{K}_{2} \mathrm{O} / \mathrm{Na}_{2} \mathrm{O}$ ratio of 2.01 is too low (e.g. Mitchell and Bergman 1991). The agpaitic index of the Krrižanovice dyke is 0.60 , a value typical of rocks of the calc-alkaline series (e.g. Liégeois et al. 1998). Abundant apatite accounts for the high $\mathrm{P}_{2} \mathrm{O}_{5}$ content (0.8 wt. \%).

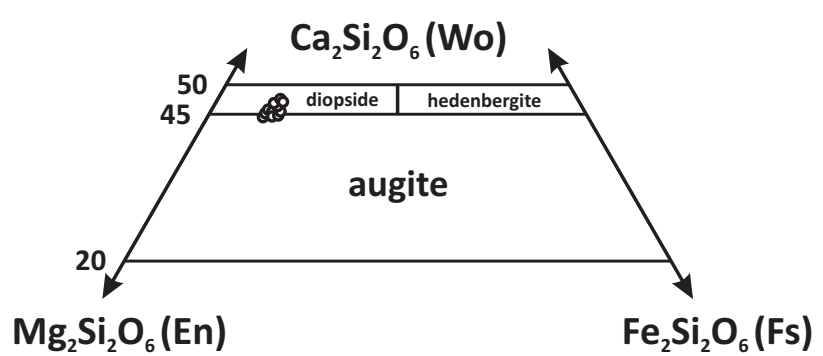

Fig. 3 Position of clinopyroxene analyses in the classification diagram of Morimoto (1988).
The Křižanovice dyke is furthermore characterized by high contents of large-ion lithophile elements (LILE) $(\mathrm{Ba}=2650 \mathrm{ppm}, \mathrm{Sr}=1050 \mathrm{ppm})$ as well as by high LILE/HFSE (high-field-strength elements) ratios (e.g. $\mathrm{Ba} / \mathrm{Nb}=217)$. The dyke also has high rare earth element contents $(\Sigma R E E=650 \mathrm{ppm})$, a very high LREE/HREE ratio (e.g. $\mathrm{Ce} / \mathrm{Yb}=138$ ) and the chondrite-normalized pattern lacks an Eu-anomaly $\left(\mathrm{Eu} / \mathrm{Eu}^{*}=0.97\right)$. The Křžzanovice dyke shows pronounced negative $\mathrm{Nb}-\mathrm{Ta}$ and $\mathrm{Ti}$ anomalies relative to chondritic abundances, a feature known solely from calc-alkaline lamprophyres (Rock 1991).

\subsection{Major-element composition of clinopyroxene and mica}

Both clinopyroxene and dark mica from the analysed sample show relatively homogeneous compositions with restricted variation between core and rim and, therefore, reflect crystallization in equilibrium with the parental magma.

Clinopyroxene crystals display normal zoning with $\mathrm{Mg}$-rich augite/diopside cores $\left(\mathrm{X}_{\mathrm{Mg}}\right.$ up to 0.86$)$ and diopside rims $\left(\mathrm{X}_{\mathrm{Mg}}=0.82\right.$; Fig. 3; Tab. 2). Calcium concentrations vary in a relatively narrow range (0.88-0.91 apfu), as do $\mathrm{Si}(1.87-1.94 a p f u)$ and tetrahedral $\mathrm{Al}(0.06-0.13$ $a p f u$ ). Chromium contents generally are below $0.01 \mathrm{apfu}$.

The major-element geochemistry of dark micas is listed in Tab. 3. All analysed crystals correspond to phlogopite (Fig. 4), which are $\mathrm{Al}_{2} \mathrm{O}_{3}$-rich (average 15.52 wt. \%) and plot into the field for micas of calc-alkaline series (Abdel-Rahman 1993, Fig. 5). The contents of Si range between 5.40 and 5.59 apfu. The phlogopite crystals are normally zoned with cores richer in $\mathrm{Mg}\left(\mathrm{X}_{\mathrm{Mg}}\right.$ up to $0.83)$ than the rims $\left(\mathrm{X}_{\mathrm{Mg}}=0.80\right)$. Tetrahedral Al lies in the range 2.41 to 2.50 apfu. Chromium contents reach 0.03 apfu in cores. All phlogopite phenocrysts are $\mathrm{OH}-$

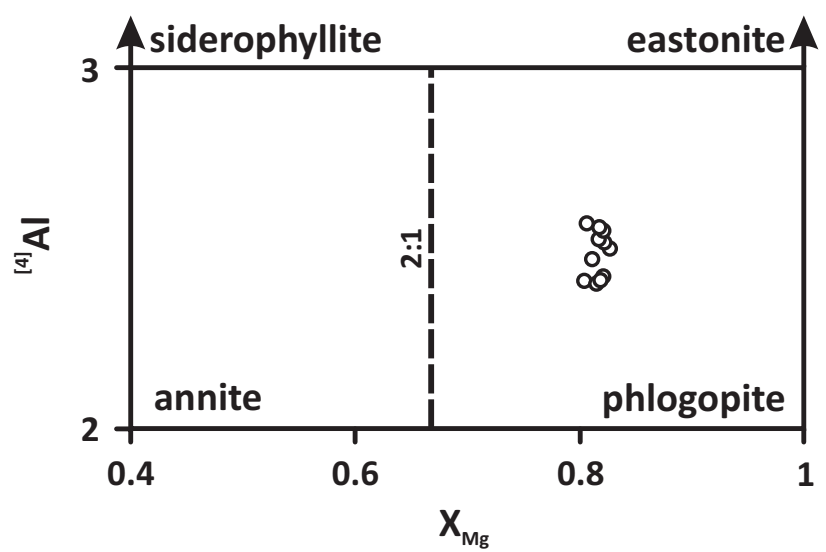

Fig. 4 Position of mica analyses in the classification diagram for K-bearing trioctahedral micas. End-member names according to Rieder et al. (1998). 
Mineral/melt and mineral/mineral partitioning in a minette

Tab. 2 Mineral chemistry (wt. \% and apfu) of clinopyroxene from the Křižanovice calc-alkaline lamprophyre

\begin{tabular}{|c|c|c|c|c|c|c|c|c|c|c|}
\hline No. & Cpx 1 & Cpx 2 & Cpx 3 & Cpx 4 & Cpx 5 & Cpx 6 & Cpx 7 & Cpx 8 & Сpх 9 & Cpx 10 \\
\hline $\mathrm{SiO}_{2}$ & 51.60 & 52.14 & 52.32 & 51.98 & 51.40 & 52.82 & 52.92 & 52.23 & 52.77 & 52.14 \\
\hline $\mathrm{TiO}_{2}$ & 0.63 & 0.40 & 0.40 & 0.58 & 0.59 & 0.40 & 0.46 & 0.40 & 0.40 & 0.55 \\
\hline $\mathrm{Al}_{2} \mathrm{O}_{3}$ & 3.32 & 1.86 & 1.77 & 3.13 & 3.22 & 1.84 & 2.39 & 1.90 & 2.06 & 2.92 \\
\hline $\mathrm{Cr}_{2} \mathrm{O}_{3}$ & 0.12 & 0.06 & 0.00 & 0.00 & 0.14 & 0.13 & 0.09 & 0.00 & 0.02 & 0.19 \\
\hline $\mathrm{FeO}^{*}$ & 5.84 & 5.35 & 5.67 & 5.40 & 5.76 & 5.12 & 5.57 & 5.26 & 6.15 & 5.33 \\
\hline $\mathrm{MnO}$ & 0.15 & 0.09 & 0.14 & 0.13 & 0.12 & 0.11 & 0.10 & 0.00 & 0.18 & 0.16 \\
\hline $\mathrm{MgO}$ & 15.65 & 16.55 & 16.52 & 15.85 & 15.83 & 17.12 & 16.54 & 16.90 & 15.94 & 15.88 \\
\hline $\mathrm{CaO}$ & 23.42 & 22.85 & 23.06 & 23.21 & 23.13 & 22.70 & 22.50 & 22.72 & 22.22 & 23.22 \\
\hline $\mathrm{Na}_{2} \mathrm{O}$ & 0.33 & 0.23 & 0.18 & 0.39 & 0.27 & 0.31 & 0.23 & 0.23 & 0.22 & 0.27 \\
\hline Total & 101.05 & 99.53 & 100.06 & 100.68 & 100.46 & 100.54 & 100.79 & 99.64 & 99.95 & 100.67 \\
\hline \multicolumn{11}{|c|}{ Formulae calculated on the basis of 4 cations with $\mathrm{Fe}^{3+}$ estimation according to Droop (1987) } \\
\hline $\mathrm{Si}$ & 1.87 & 1.92 & 1.92 & 1.89 & 1.88 & 1.92 & 1.92 & 1.91 & 1.94 & 1.90 \\
\hline $\mathrm{Ti}$ & 0.02 & 0.01 & 0.01 & 0.02 & 0.02 & 0.01 & 0.01 & 0.01 & 0.01 & 0.02 \\
\hline${ }^{[4]} \mathrm{Al}$ & 0.13 & 0.08 & 0.08 & 0.11 & 0.12 & 0.08 & 0.08 & 0.08 & 0.06 & 0.10 \\
\hline${ }^{[6]} \mathrm{Al}$ & 0.02 & 0.00 & 0.00 & 0.02 & 0.01 & 0.00 & 0.02 & 0.00 & 0.03 & 0.02 \\
\hline $\mathrm{Cr}$ & 0.00 & 0.00 & 0.00 & 0.00 & 0.00 & 0.00 & 0.00 & 0.00 & 0.00 & 0.01 \\
\hline $\mathrm{Fe}^{3+}$ & 0.10 & 0.08 & 0.08 & 0.08 & 0.09 & 0.08 & 0.04 & 0.08 & 0.02 & 0.06 \\
\hline $\mathrm{Fe}^{2+}$ & 0.08 & 0.08 & 0.09 & 0.08 & 0.08 & 0.07 & 0.13 & 0.08 & 0.17 & 0.10 \\
\hline $\mathrm{Mn}$ & 0.00 & 0.00 & 0.00 & 0.00 & 0.00 & 0.00 & 0.00 & 0.00 & 0.01 & 0.00 \\
\hline $\mathrm{Mg}$ & 0.85 & 0.91 & 0.90 & 0.86 & 0.86 & 0.93 & 0.90 & 0.92 & 0.87 & 0.86 \\
\hline $\mathrm{Ca}$ & 0.91 & 0.90 & 0.90 & 0.90 & 0.90 & 0.88 & 0.88 & 0.89 & 0.88 & 0.91 \\
\hline $\mathrm{Na}$ & 0.02 & 0.02 & 0.01 & 0.03 & 0.02 & 0.02 & 0.02 & 0.02 & 0.02 & 0.02 \\
\hline$\Sigma$ & 4.00 & 4.00 & 4.00 & 4.00 & 4.00 & 4.00 & 4.00 & 4.00 & 4.00 & 4.00 \\
\hline $\mathrm{X}_{\mathrm{Mg}}$ & 0.83 & 0.85 & 0.84 & 0.84 & 0.83 & 0.86 & 0.84 & 0.85 & 0.82 & 0.84 \\
\hline \multicolumn{11}{|c|}{$\mathrm{Ca}_{2} \mathrm{Si}_{2} \mathrm{O}_{6}(\mathrm{Wo}), \mathrm{Mg}_{2} \mathrm{Si}_{2} \mathrm{O}_{6}(\mathrm{En})$ and $\mathrm{Fe}_{2} \mathrm{Si}_{2} \mathrm{O}_{6}(\mathrm{Fs})$ end-members (mol. \%) } \\
\hline Wo & 47 & 46 & 46 & 47 & 47 & 45 & 45 & 45 & 45 & 47 \\
\hline En & 44 & 46 & 45 & 44 & 44 & 47 & 46 & 47 & 45 & 45 \\
\hline Fs & 9 & 8 & 9 & 9 & 9 & 8 & 9 & 8 & 10 & 8 \\
\hline
\end{tabular}

dominant (eventually oxy-dominant) with only limited contents of $\mathrm{F}(0.18-0.26$ apfu) and $\mathrm{Cl}(0.01-0.02$ apfu).

\subsection{Clinopyroxene/matrix, phlogopite/matrix and clinopyroxene/phlogopite trace element partitioning}

In clinopyroxene/matrix pairs, only $\mathrm{Cs}, \mathrm{Ba}, \mathrm{Rb}, \mathrm{Sr}, \mathrm{U}$, Th, Ta, Zr, Hf, Ti, Y, La, Ce, Pr, Nd, Sm, Tb, Dy, Ho, Er,

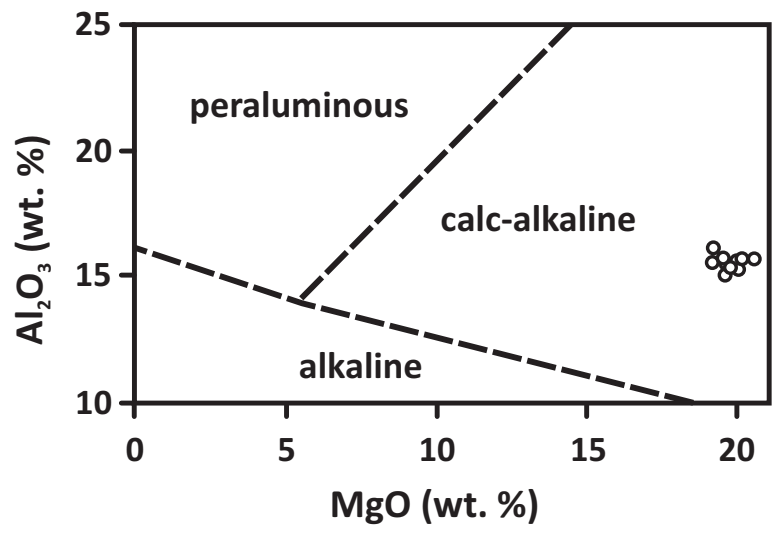

Fig. 5 Position of mica analyses in the classification diagram of Abdel-Rahman (1993) for micas from different magmatic series.
$\mathrm{Tm}, \mathrm{Yb}$, and $\mathrm{Lu}$ were found above their respective detection limits. The majority of these elements yield partition coefficients between clinopyroxene and melt markedly below 1 (Tab. 4). In contrast, heavy rare earth elements (HREE) have clinopyroxene/matrix $D_{\text {HREE }} \sim 1$ (Tb: 1.05, Dy: 1.07, Ho: 0.97, Er: 1.07, Tm: 0.99, Yb: 0.92, Lu: 0.95, Fig. 6).

In phlogopite/matrix pairs, only 15 elements had concentrations above detection limit (Cs, Ba, $\mathrm{Rb}, \mathrm{Sr}, \mathrm{U}, \mathrm{Th}$, Ta, Zr, Hf, Ti, Y, La, Ce, Pr and Nd). Phlogopite/matrix partition coefficients are greater than 1 for $\mathrm{Ba}(1.11)$ and $\mathrm{Rb}$ (1.66) (Fig. 7, Tab. 4). Beside $\mathrm{Ba}$ and $\mathrm{Rb}$, we found that $\mathrm{Ti}$ also has a tendency to partition into phlogopite during its crystallization from lamprophyric melt (phlogopite/ ${ }_{\text {matrix }} D_{\mathrm{Ti}}=1.50$ ), a fact not reported in previous studies. In contrast to $\mathrm{Ba}, \mathrm{Rb}$ and $\mathrm{Ti}$, the phlogopite/matrix $D$ values for LREE are extremely low $(D \leq 0.02)$ and it was not possible to determine ${ }^{\text {phlogopite/matrix } D}$ values for $\mathrm{Nb}$ and the majority of HREE.

The clinopyroxene/phlogopite $D$ values obtained in this study (Tab. 4) indicate that clinopyroxene and phlogopite phenocrysts preferentially incorporate different trace elements and, therefore, will strongly affect the fractionation behaviour of the melt. Thorium ( ${ }^{\text {clinopyroxene/phlogopite }} D$ = 1.66), $\mathrm{Zr}$ (1.84), Hf (2.65) and LREE ( $\mathrm{La}, \mathrm{Ce}, \mathrm{Pr}, \mathrm{Nd}$ ) 
Tab. 3 Mineral chemistry (wt. \% and apfu) of phlogopite from the Křižanovice calc-alkaline lamprophyre

\begin{tabular}{|c|c|c|c|c|c|c|c|c|c|c|}
\hline No. & Phl 1 & Phl 2 & Phl 3 & Phl 4 & Phl 5 & Phl 6 & Phl 7 & Phl 8 & Phl 9 & Phl 10 \\
\hline $\mathrm{SiO}_{2}$ & 38.28 & 38.55 & 37.49 & 38.37 & 38.82 & 38.72 & 37.04 & 37.43 & 37.90 & 37.07 \\
\hline $\mathrm{TiO}_{2}$ & 3.78 & 3.45 & 3.70 & 3.66 & 3.72 & 3.67 & 3.96 & 3.69 & 3.63 & 3.49 \\
\hline $\mathrm{Al}_{2} \mathrm{O}_{3}$ & 16.15 & 15.27 & 15.24 & 15.64 & 15.02 & 15.49 & 15.62 & 15.62 & 15.65 & 15.50 \\
\hline $\mathrm{Cr}_{2} \mathrm{O}_{3}$ & 0.09 & 0.20 & 0.17 & 0.00 & 0.25 & 0.00 & 0.07 & 0.12 & 0.07 & 0.19 \\
\hline $\mathrm{FeO}^{*}$ & 8.01 & 7.66 & 8.00 & 7.76 & 7.96 & 8.42 & 8.48 & 8.00 & 7.81 & 7.78 \\
\hline $\mathrm{NiO}$ & 0.00 & 0.00 & 0.13 & 0.00 & 0.00 & 0.00 & 0.00 & 0.00 & 0.00 & 0.00 \\
\hline $\mathrm{MnO}$ & 0.00 & 0.00 & 0.05 & 0.00 & 0.00 & 0.10 & 0.00 & 0.00 & 0.00 & 0.07 \\
\hline $\mathrm{MgO}$ & 19.28 & 19.88 & 20.17 & 20.77 & 19.72 & 19.25 & 19.61 & 20.32 & 20.33 & 20.04 \\
\hline $\mathrm{CaO}$ & 0.05 & 0.00 & 0.07 & 0.11 & 0.10 & 0.00 & 0.00 & 0.00 & 0.07 & 0.00 \\
\hline $\mathrm{Na}_{2} \mathrm{O}$ & 0.34 & 0.59 & 0.38 & 0.48 & 0.55 & 0.36 & 0.76 & 0.71 & 0.67 & 0.70 \\
\hline $\mathrm{K}_{2} \mathrm{O}$ & 8.59 & 8.68 & 8.63 & 8.74 & 8.59 & 8.74 & 8.50 & 8.79 & 8.49 & 8.82 \\
\hline $\mathrm{BaO}$ & 1.34 & 1.27 & 1.26 & 1.20 & 1.26 & 1.22 & 1.47 & 1.31 & 1.32 & 1.26 \\
\hline $\mathrm{F}$ & 0.49 & 0.55 & 0.41 & 0.59 & 0.57 & 0.43 & 0.39 & 0.43 & 0.47 & 0.43 \\
\hline $\mathrm{Cl}$ & 0.05 & 0.06 & 0.04 & 0.04 & 0.05 & 0.06 & 0.06 & 0.04 & 0.05 & 0.03 \\
\hline Subtotal & 96.44 & 96.16 & 95.73 & 97.35 & 96.61 & 96.45 & 95.96 & 96.46 & 96.45 & 95.36 \\
\hline $\mathrm{H}_{2} \mathrm{O}^{*}$ & 3.92 & 3.87 & 3.91 & 3.91 & 3.88 & 3.94 & 3.91 & 3.93 & 3.92 & 3.88 \\
\hline $\mathrm{O}=(\mathrm{F}, \mathrm{Cl})$ & 0.22 & 0.24 & 0.18 & 0.26 & 0.25 & 0.19 & 0.18 & 0.19 & 0.21 & 0.19 \\
\hline Total & 100.15 & 99.79 & 99.46 & 101.00 & 100.24 & 100.20 & 99.69 & 100.20 & 100.17 & 99.06 \\
\hline \multicolumn{11}{|c|}{ Formula calculated on the basis of 22 oxygens; $\mathrm{H}_{2} \mathrm{O}$ estimated from electroneutral formula and $(\mathrm{OH}, \mathrm{F}, \mathrm{Cl})=4$} \\
\hline $\mathrm{Si}$ & 5.51 & 5.57 & 5.46 & 5.48 & 5.59 & 5.58 & 5.40 & 5.42 & 5.47 & 5.43 \\
\hline [4]Al & 2.49 & 2.43 & 2.54 & 2.52 & 2.41 & 2.42 & 2.60 & 2.58 & 2.53 & 2.57 \\
\hline$\Sigma$ & 8.00 & 8.00 & 8.00 & 8.00 & 8.00 & 8.00 & 8.00 & 8.00 & 8.00 & 8.00 \\
\hline [6]Al & 0.26 & 0.18 & 0.08 & 0.12 & 0.14 & 0.22 & 0.09 & 0.08 & 0.13 & 0.10 \\
\hline $\mathrm{Ti}$ & 0.41 & 0.37 & 0.41 & 0.39 & 0.40 & 0.40 & 0.43 & 0.40 & 0.39 & 0.38 \\
\hline $\mathrm{Cr}$ & 0.01 & 0.02 & 0.02 & 0.00 & 0.03 & 0.00 & 0.01 & 0.01 & 0.01 & 0.02 \\
\hline $\mathrm{Fe}$ & 0.96 & 0.93 & 0.97 & 0.93 & 0.96 & 1.02 & 1.03 & 0.97 & 0.94 & 0.95 \\
\hline $\mathrm{Mn}$ & 0.00 & 0.00 & 0.01 & 0.00 & 0.00 & 0.01 & 0.00 & 0.00 & 0.00 & 0.01 \\
\hline $\mathrm{Mg}$ & 4.14 & 4.28 & 4.38 & 4.42 & 4.23 & 4.14 & 4.26 & 4.39 & 4.37 & 4.37 \\
\hline $\mathrm{Ni}$ & 0.00 & 0.00 & 0.02 & 0.00 & 0.00 & 0.00 & 0.00 & 0.00 & 0.00 & 0.00 \\
\hline $\mathrm{Ca}$ & 0.01 & 0.00 & 0.01 & 0.02 & 0.02 & 0.00 & 0.00 & 0.00 & 0.01 & 0.00 \\
\hline $\mathrm{Na}$ & 0.09 & 0.16 & 0.11 & 0.13 & 0.15 & 0.10 & 0.22 & 0.20 & 0.19 & 0.20 \\
\hline $\mathrm{K}$ & 1.58 & 1.60 & 1.60 & 1.59 & 1.58 & 1.61 & 1.58 & 1.62 & 1.56 & 1.65 \\
\hline $\mathrm{Ba}$ & 0.08 & 0.07 & 0.07 & 0.07 & 0.07 & 0.07 & 0.08 & 0.07 & 0.07 & 0.07 \\
\hline$\Sigma$ & 7.54 & 7.62 & 7.67 & 7.67 & 7.58 & 7.56 & 7.71 & 7.75 & 7.68 & 7.76 \\
\hline $\mathrm{OH}^{*}$ & 3.77 & 3.73 & 3.80 & 3.73 & 3.73 & 3.79 & 3.80 & 3.79 & 3.78 & 3.79 \\
\hline $\mathrm{F}$ & 0.22 & 0.25 & 0.19 & 0.26 & 0.26 & 0.20 & 0.18 & 0.20 & 0.21 & 0.20 \\
\hline $\mathrm{Cl}$ & 0.01 & 0.01 & 0.01 & 0.01 & 0.01 & 0.01 & 0.02 & 0.01 & 0.01 & 0.01 \\
\hline$\Sigma$ & 4.00 & 4.00 & 4.00 & 4.00 & 4.00 & 4.00 & 4.00 & 4.00 & 4.00 & 4.00 \\
\hline $\mathrm{X}_{\mathrm{Mg}}$ & 0.81 & 0.82 & 0.82 & 0.83 & 0.82 & 0.80 & 0.80 & 0.82 & 0.82 & 0.82 \\
\hline
\end{tabular}

are partitioned into clinopyroxene, whereas $\mathrm{Ba}(0.03)$, $\mathrm{Cs}(0.24), \mathrm{Rb}(0.15), \mathrm{Ta}(0.21)$ and $\mathrm{Ti}(0.24)$ strongly fractionate into phlogopite (Fig. 8).

\section{Discussion}

The main purpose of this paper is to present a representative set of $D$-values for a typical calc-alkaline lamprophyre. The differences in trace-element partitioning coefficients between our study and those of Foley et al. (1996) and Plá Cid et al. (2005) can generally be explained as follows: (1) different alkalinity and degree of evolution of the studied "lamprophyre" system and
(2) distinct $P-T$ conditions of crystallization of individual phases.

The clinopyroxene/matrix $D$ values for HREE are $\sim 1$, which is c. 3 times higher than the partition coefficients of Foley et al. (1996) observed in clinopyroxene growing from an alkaline melt. This suggests that HREE are partitioned into clinopyroxene to much higher extent than indicated by Foley et al. (1996). Actually these higher clinopyroxene/ matrix $D$ values are in line with results from near-solidus melting experiments of on spinel lherzolite producing melt of basaltic composition (Blundy et al. 1998). Plá Cid et al. (2005) obtained even higher clinopyroxene/matrix $D_{\text {HRRE }}$ values for very high-pressure mafic microgranular enclaves containing K-pyroxene. Similar differences also exist for 
Tab. 4 Calculated clinopyroxene/matrix $\left({ }^{\mathrm{Cpx} / \mathrm{matrix}} D\right)$, phlogopite/matrix $\left({ }^{\mathrm{Phl} / \mathrm{matrix}} D\right)$ and clinopyroxene/phlogopite $\left({ }^{\mathrm{Cpx} / \mathrm{Phl}} D\right)$ partition coefficients for the Křižanovice calc-alkaline lamprophyre together with values reported by Foley et al. (1996) and Plá Cid et al. (2005)

\begin{tabular}{|c|c|c|c|c|c|c|c|c|c|c|}
\hline & $\begin{array}{c}{ }^{\mathrm{Cpx} / \text { matrix }} D \\
\text { (this study) }\end{array}$ & $1 \sigma$ & $\begin{array}{c}{ }^{\mathrm{Cpx} / \text { matrix }} D \\
\text { (Foley et al. } \\
1996)\end{array}$ & $\begin{array}{c}{ }^{C p x / m a t r i x} D \\
\text { (Plá Cid et al. } \\
2005)\end{array}$ & $\begin{array}{c}{ }^{\mathrm{Ph} l / \text { matrix }} D \\
\text { (this study) }\end{array}$ & $1 \sigma$ & $\begin{array}{c}{ }^{\text {Phl/matrix } D} \\
\text { (Foley et al. } \\
1996)\end{array}$ & $\begin{array}{c}{ }_{\text {Phl } / \text { matrix }} D \\
\text { (Plá Cid et al. } \\
2005)\end{array}$ & $\begin{array}{c}{ }^{\mathrm{Cpx} / \mathrm{Phl}} D \\
\text { (this study) }\end{array}$ & $1 \sigma$ \\
\hline Cs & 0.127 & 0.02 & & & 0.437 & 0.03 & 0.626 & & 0.240 & 0.03 \\
\hline $\mathrm{Ba}$ & 0.031 & 0.008 & 0.00061 & $<0.0004$ & 1.107 & 0.04 & 3.48 & $0.45-0.47$ & 0.026 & 0.006 \\
\hline $\mathrm{Rb}$ & 0.286 & 0.15 & 0.0047 & 0.012 & 1.658 & 0.06 & 5.18 & $2.01-2.05$ & 0.152 & 0.02 \\
\hline $\mathrm{Sr}$ & 0.218 & 0.14 & 0.0963 & $0.17-0.21$ & 0.372 & 0.03 & 0.183 & 0.0057 & 0.537 & 0.02 \\
\hline $\mathrm{Th}$ & 0.056 & 0.01 & 0.0056 & $<0.014$ & 0.034 & 0.006 & $<0.0145$ & 0.0016 & 1.657 & 0.09 \\
\hline $\mathrm{U}$ & 0.100 & 0.02 & & & 0.141 & 0.02 & & & 0.491 & 0.04 \\
\hline $\mathrm{Ta}$ & 0.044 & 0.05 & & & 0.155 & 0.03 & 0.1069 & & 0.210 & 0.02 \\
\hline $\mathrm{Zr}$ & 0.258 & 0.03 & 0.121 & $0.37-0.41$ & 0.148 & 0.02 & 0.0232 & $<0.0028$ & 1.844 & 0.09 \\
\hline Hf & 0.442 & 0.02 & & $0.46-0.53$ & 0.182 & 0.02 & & & 2.647 & 0.1 \\
\hline $\mathrm{Ti}$ & 0.390 & 0.02 & & & 1.496 & 0.05 & & & 0.242 & 0.02 \\
\hline $\mathrm{Y}$ & 0.719 & 0.04 & 0.438 & 1.46 & 0.039 & 0.005 & 0.007 & 0.0012 & 18.151 & 0.8 \\
\hline $\mathrm{La}$ & 0.153 & 0.03 & 0.0435 & $0.16-0.20$ & 0.021 & 0.003 & & $0.002-0,008$ & 7.272 & 0.5 \\
\hline $\mathrm{Ce}$ & 0.287 & 0.01 & 0.0843 & $0.33-0.41$ & 0.021 & 0.004 & 0.0078 & $<0.005$ & 13.366 & 0.3 \\
\hline $\operatorname{Pr}$ & 0.452 & 0.02 & 0.124 & $0.47-0.58$ & 0.022 & 0.002 & & & 18.757 & 0.7 \\
\hline $\mathrm{Nd}$ & 0.678 & 0.03 & 0.173 & $0.51-0.63$ & 0.019 & 0.002 & & $<0.0045$ & 32.051 & 0.9 \\
\hline $\mathrm{Sm}$ & 0.903 & 0.05 & 0.283 & $0.80-1.07$ & & & & $<0.0016$ & & \\
\hline $\mathrm{Tb}$ & 1.051 & 0.03 & 0.364 & & & & & & & \\
\hline Dy & 1.074 & 0.04 & 0.363 & $1.20-1.37$ & & & & & & \\
\hline Ho & 0.967 & 0.03 & 0.378 & $1.36-1.52$ & & & & & & \\
\hline $\mathrm{Er}$ & 1.068 & 0.03 & 0.351 & 1.46 & & & & & & \\
\hline $\mathrm{Tm}$ & 0.988 & 0.02 & 0.297 & & & & & & & \\
\hline $\mathrm{Yb}$ & 0.916 & 0.04 & 0.313 & $1.09-1.52$ & & & & $<0.0018$ & & \\
\hline $\mathrm{Lu}$ & 0.950 & 0.03 & 0.265 & & & & & & & \\
\hline
\end{tabular}

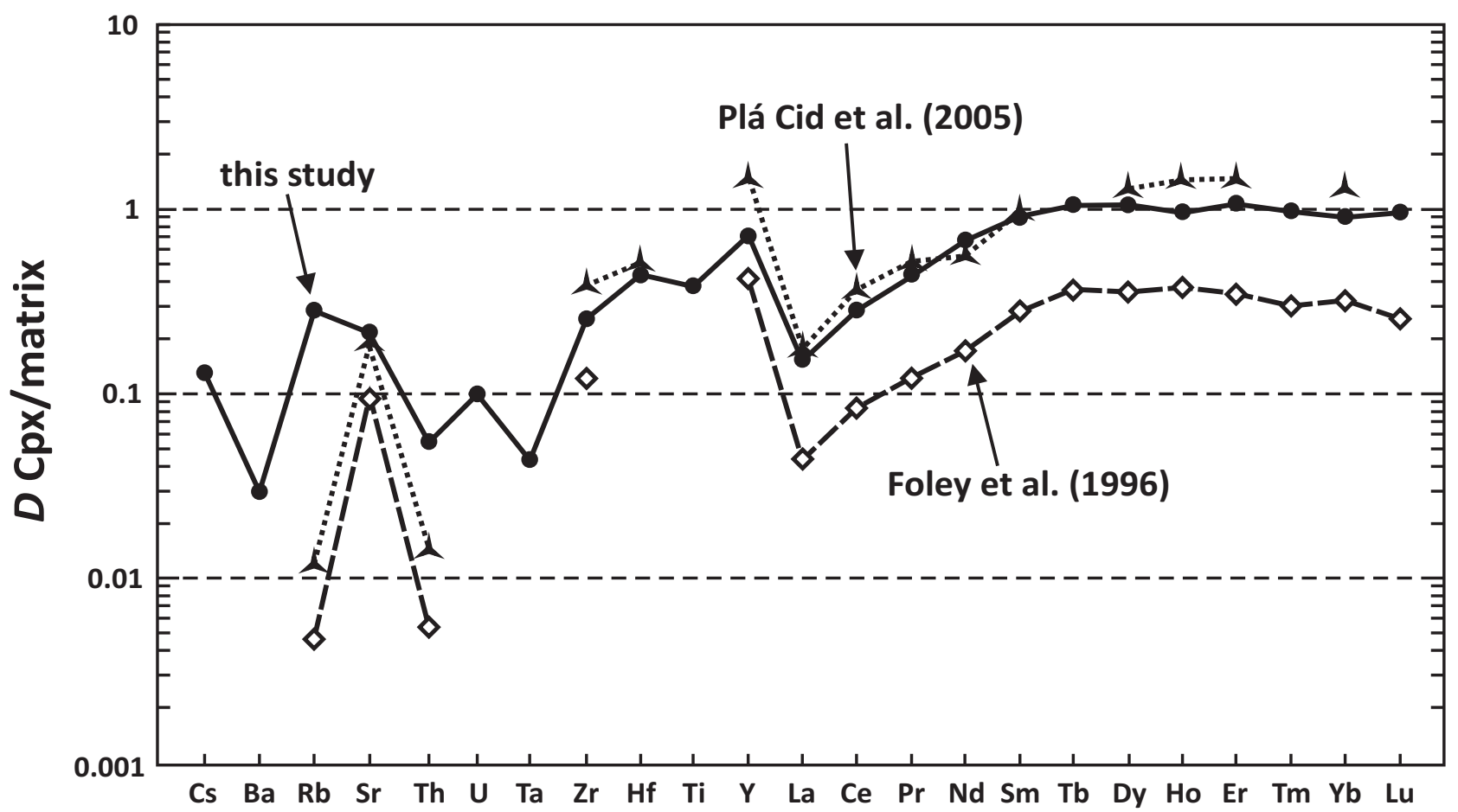

Fig. 6 Average partition coefficients for individual elements in clinopyroxene/matrix pairs (Foley et al. 1996; Plá Cid et al. 2005 and this study). Not plotted are clinopyroxene/matrix $D_{\mathrm{Ba}}$ values $<<0.001$. Order of elements according to Foley and Jenner (2004). 


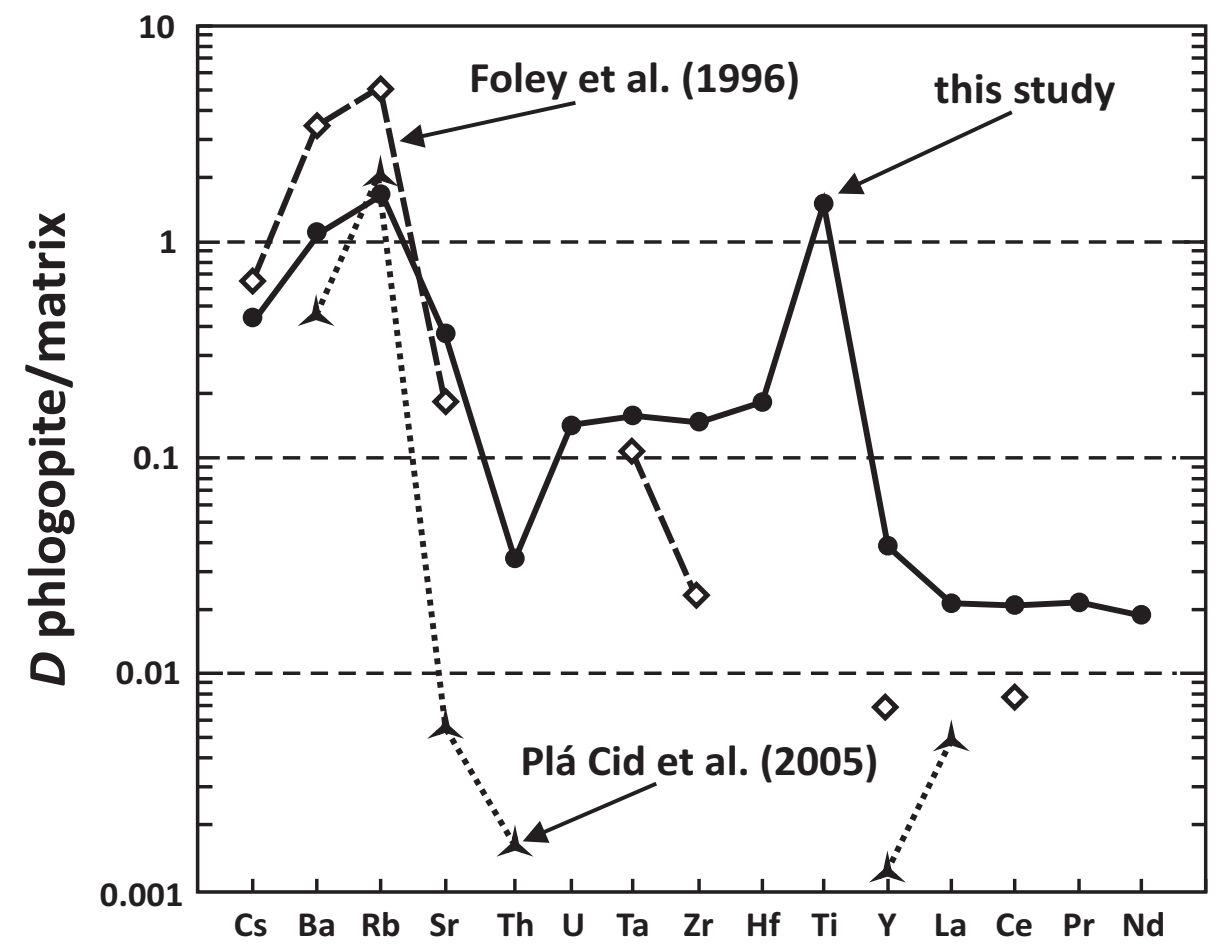

Fig. 7 Average partition coefficients for individual elements in phlogopite/ matrix pairs (Foley et al. 1996; Plá Cid et al. 2005 and this study). the partitioning of $\mathrm{Y}$. The ${ }^{\text {clinopyroxene/matrix }} D_{\mathrm{Y}}$ determined in this study is 0.72, whereas Foley et al. (1996) gave - consistently with the HREE - a lower ${ }^{\text {clinopyroxene/matrix }} D_{\mathrm{Y}}$ value (0.44) and Plá Cid et al. (2005) a markedly higher value (clinopyroxene/matrix $D_{\mathrm{Y}}=1.46$ ).

There is a remarkable difference between the phlogopite/ ${ }^{\text {matrix }} D_{\mathrm{Ba}, \mathrm{Rb}}$ values obtained in this study and the values

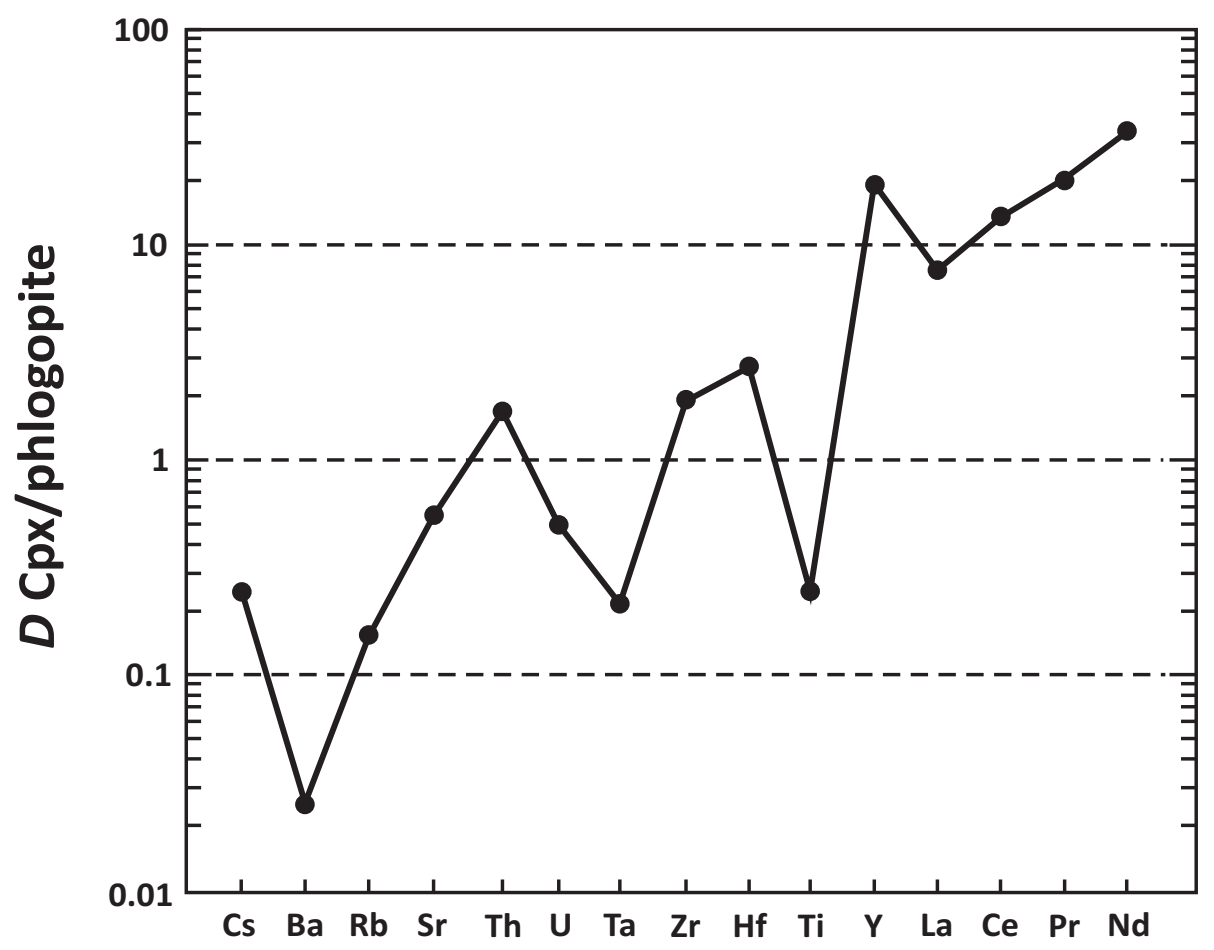

from previous works. The highest phlogopite/matrix $D$ value in the Křižanovice lamprophyre was observed for Rb, which may account for the contrasting composition of dykes within the same area. In the Železné hory Mts., two spatially associated Variscan generations of phlogopite bearing mafic dykes occur (calc-alkaline lamprophyres and cocites). The calc-alkaline lamprophyres ( 340-335 Ma) seem to be slightly older than the cocites $(\sim 332-330 \mathrm{Ma}$; Krmíček et al. 2008; Krmíček 2011). The latter, which compositionally resemble Mediterranean lamproitic rocks (Prelević et al. 2013 and references therein), have more than seven times higher Rb contents than the older calc-alkaline lamprophyres in the same area (Krmíček 2011). Although the different $\mathrm{Rb}$ contents of dykes from the two groups could reflect contrasting extent of melting of distinct sources sharing a similar composition, we favour a different explanation involving the repeated melting of the same source. In the lat-

Fig. 8 Average partition coefficients for individual elements in clinopyroxene/ phlogopite pairs from the calc-alkaline lamprophyre of this study. 
ter case, the two types of dykes in the Železné hory Mts. could have been derived by repeated low-degree partial melting of previously metasomatised (phlogopitised) upper mantle. The early melts would not have exceedingly high $\mathrm{Rb}$ contents unless phlogopite was completely consumed during melting and $\mathrm{Rb}$ released during melting of phlogopite would be partitioned between melt and residual phlogopite. Subsequent partial melting consuming residual phlogopite would produce melts initially strongly enriched in $\mathrm{Rb}$. Such a two-step process for the formation of cocites, with an early modification of the metasomatised mantle and subsequent decomposition of residual phlogopite, also may explain why cocites are rare.

During simultaneous crystallization of clinopyroxene and phlogopite phenocrysts, Th, Zr, Hf, Y and LREE were preferentially partitioned into clinopyroxene. The apparent exclusion of these elements from the phlogopite structure is driven by the unfavourable effective ionic radii and charges of these ions. Effective ionic radii are strongly dependant on charge and on coordination (e.g. Shannon 1976). Considering the six-fold coordination with oxygen (Schmidt et al. 1999), it is obvious that not only the tetrahedral and alkali sites, but also the six-fold coordinated $M 1$ and $M 2$ sites are inappropriate for the incorporation of $\mathrm{LREE}^{3+}, \mathrm{Y}^{3+}, \mathrm{Th}^{4+}, \mathrm{Zr}^{4+}$ and $\mathrm{Hf}^{4+}$ (Shannon 1976). Thus, the main reason for observed partitioning may be connected with lack of a suitable crystallographic site in phlogopite structure for six-fold coordinated $\mathrm{REE}^{3+}, \mathrm{Th}^{4+}, \mathrm{Zr}^{4+}$, and $\mathrm{Hf}^{4+}$ (see Schmidt et al. 1999). Zirconium and Hf partitioning into clinopyroxene, however, could be significantly affected by the crystallization of $\mathrm{Zr}$-sequestering phases reflecting the peralkalinity of the system. Whereas zircon as major Zr-carrier is typically not present in calc-alkaline lamprophyres, accessory titanite may dominate the $\mathrm{Zr}$ budget of these rocks (Seifert and Kramer 2003). Zircon and titanite are not known from the Křžanovice dyke and, therefore, clinopyroxene seems to be the major $\mathrm{Zr}$ and Hf host, at least in the studied calc-alkaline lamprophyre. The contrasting fractionation behaviour of the two trace-element groups (Th, Zr, Hf and LREE vs. Ba, Cs, Rb, Ta and Ti) into clinopyroxene and phlogopite, respectively, will result in different trace-element signatures depending on the fractionation history of the rock. The two element groups will uncouple from each other if clinopyroxene or phlogopite crystallizes and will behave coherently if clinopyroxene and phlogopite crystallize.

\section{Conclusions}

Phlogopite/matrix, clinopyroxene/matrix and clinopyroxene/phlogopite partition coefficients were determined for a calc-alkaline lamprophyre with Mg-number close to those of typical mantle-derived melts. Among the clinopyroxene/matrix partition coefficients for trace elements, only those for HREE are close to unity. Phlogopite/matrix partition coefficients are high for $\mathrm{Ba}, \mathrm{Rb}$ and $\mathrm{Ti}$, whereas those for LREE (and by inference HREE) are very low (phlogopite/matrix $D \leq 0.02$ ). Thus, during simultaneous crystallization of clinopyroxene and phlogopite phenocrysts, $\mathrm{Th}$, $\mathrm{Zr}, \mathrm{Hf}, \mathrm{Y}$ and LREE are preferentially partitioned into clinopyroxene, and $\mathrm{Ba}$ with $\mathrm{Rb}$ and $\mathrm{Ti}$ into phlogopite.

Acknowledgements. Thoughtful reviews by Stephen F. Foley and an anonymous reviewer as well as editorial handlig of F. V. Holub helped to improve the original manuscript. We gratefully appreciate comments made by Editor-in-Chief V. Janoušek. The work was supported by the project "EXCELLENT TEAMS" at Brno University of Technology; registration number CZ.1.07/2.3.00/30.0005. MVG and TV also acknowledge the European Regional Development Fund project "CEITEC" (CZ.1.05/1.1.00/02.0068). Printing costs were covered by the project "IRICoN".

\section{References}

Abdel-Rahman AM (1993) Nature of biotites from alkaline, calcalkaline, and peraluminous magmas. J Petrol 35: 525-541

Blundy J, Wood B (2003) Partitioning of trace elements between crystals and melts. Earth Planet Sci Lett 210: 381-398

Blundy JD, Robinson JAC, Wood B (1998) Heavy REE are compatible in clinopyroxene on the spinel lherzolite solidus. Earth Planet Sci Lett 160: 493-504

Droop GTR (1987) A general equation for estimating $\mathrm{Fe}^{3+}$ concentrations in ferromagnesian silicates and oxides from microprobe analyses, using stoichiometric criteria. Mineral Mag 51: 431-435

Foley SF, Jenner GA (2004) Trace element partitioning in lamproitic magmas - the Gaussberg olivine leucitite. Lithos 75:19-38

Foley SF, Jackson SE, Fryer BJ, Greenough JD, Jenner GA (1996) Trace element partition coefficients for clinopyroxene and phlogopite in an alkaline lamprophyre from Newfoundland by LAM-ICP-MS. Geochim Cosmochim Acta 60: 629-638

Foley SF, Prelević D, Rehfeldt T, Jacob D (2013) Minor and trace elements in olivine as probes into early igneous and mantle melting processes. Earth Planet Sci Lett 363: 181-191

Fritschle T, Prelević D, Foley SF, Jacob DE (2013) Petrological characterization of the mantle source of Mediterranean lamproites: indications from major and trace elements of phlogopite. Chem Geol 353: 267-279 
GüMBEL CW (1874) Die paläolithischen Eruptivgesteine des Fichtelgebirges. Königlichen Ludwig-MaximiliansUniversität, München, pp 1-50

GöTzE J (2012) Application of cathodoluminescence microscopy and spectroscopy in geosciences. Microsc Microanal 18: 1270-1284

HÁJek J, ŠpaČEK J, Drozen J (1997) The Železné Hory Pluton and its mantle rocks. Sbor Geol Věd, Ložisk Geol Mineral 31: 51-66

Klimm K, Blundy JD, Green TH (2008) Trace element partitioning and accessory phase saturation during $\mathrm{H}_{2} \mathrm{O}$-saturated melting of basalt with implications for subduction zone chemical fluxes. J Petrol 49: 523-553

KlomínskÝ J, JARChOVsKÝ T, RAJPOOT GS (2010) Atlas of Plutonic Rocks and Orthogneisses in the Bohemian Massif - 1. Bohemicum. Czech Geological Survey, Prague, pp $1-100$

KRMíČEK L (2011) Pre-Mesozoic Dyke Lamprophyres from the Eastern Part of the Bohemian Massif. Unpublished Ph.D. Thesis, Masaryk University, Brno, pp 1-133 (in Czech)

KRMíČEK L, RoMer RL (2013) Are mafic microgranular enclaves in durbachites plutonic equivalents of common minettes? Mineral Mag 77: 1514

Krmíčex L, Přichystal A, Timmerman MJ, Halavínová M (2008) Lower Carboniferous ultrapotassic lamprophyres near the Bohemicum/Moldanubicum boundary: an example from the Železné hory Mts. (Czech Republic). In: Breitkreuz Ch, Hoffmann U, Renno AD, StaneK K (eds) Third VENTS Field Workshop, Abstract Volume and Field Guide on the Late Paleozoic Magmatic Evolution of Saxony. Wissenschaftliche Mitteilungen, Technische Universität Bergakademie Freiberg, pp 8-10

Liégeois JP, Navez J, Hertogen J, Black R (1998) Contrasting origin of post-collisional high-K calc-alkaline and shoshonitic versus alkaline and peralkaline granitoids. The use of sliding normalization. Lithos 45: 1-28

Mitchell RH, Bergman SC (1991) Petrology of Lamproites. Plenum Press, New York, pp 1-447

Morimoto CN (1988) Nomenclature of pyroxenes. Mineral Mag 52: 535-550

NĚMEC D (1991) Minettes of the Železné hory Mountains (Iron Mts.), Eastern Bohemia. Scr Univ Masaryk Brun, Geol 21: 63-90

Peccerillo A, Taylor SR (1976) Geochemistry of Eocene calc-alkaline volcanic rocks from the Kastamonu area, northern Turkey. Contrib Mineral Petrol 58: 63-81
Plá Cid J, Nardi LVS, Enrique P, Merlet C, Boyer B (2005) SIMS analyses on trace and rare earth elements in coexisting clinopyroxene and mica from minette mafic enclaves in potassic syenites crystallized under high pressures. Contrib Mineral Petrol 148: 675-688

Pouchou JL, Pichoir F (1985) “PAP” $\phi(\rho Z)$ procedure for improved quantitative microanalysis. Microbeam Analysis 20: 104-106

Prelević D, Jacob DE, Foley SF (2013) A new recipe for the formation of Alpine-Himalayan orogenic mantle lithosphere. Earth Planet Sci Lett 362: 187-197

Rieder M, Cavazzini G, D'Yakonov YS, Frank-KamenetskiI VA, Gottardi G, Guggenheim S, Koval PV, Müller G, Neiva AMr, Radoslovich EW, Robert JL, SAssi FP, TAKedA H, Weiss Z, Wones DR (1998) Nomenclature of micas. Canad Mineral 36: 905-912

Rock NMS (1991) Lamprophyres. Blackie, Glasgow and London, pp 1-285

Scarrow JH, Bea F, Montero P, Molina JF (2008) Shoshonites, vaugnerites and potassic lamprophyres: similarities and differences between 'ultra'-high-K rocks. Trans Roy Soc Edinb, Earth Sci 99: 159-175

Seifert W, Kramer W (2003) Accessory titanite: an important carrier of zirconium in lamprophyres. Lithos 71: 81-98

Schmidt KH, Bottazzi P, Vannucci R, Mengel K (1999) Trace element partitioning between phlogopite, clinopyroxene and leucite lamproite melt. Earth Planet Sci Lett 168: 287-299

SHAND SJ (1943) Eruptive Rocks: Their Genesis, Composition, and Classification, with a Chapter on Meteorites. John Wiley and Sons, New York, pp 1-444

SHANNON RD (1976) Revised effective ionic radii and systematic studies of interatomic distances in halides and chalcogenides. Acta Cryst A32: 751-767

Simon S, Wilke M, Chernikov R, Klemme S, Hennet L (2013) The influence of composition on the local structure around yttrium in quenched silicate melts - insights from EXAFS. Chem Geol 346: 3-13

SŁABy E, Götze J (2004) Feldspar crystallization under magma-mixing conditions shown by cathodoluminescence and geochemical modelling - a case study from the Karkonosze Pluton (SW Poland). Mineral Mag 68: 561-577

Tommasini S, Avanzinelli R, Conticelli S (2011) The Th/La and $\mathrm{Sm} / \mathrm{La}$ conundrum of the Tethyan realm lamproites. Earth Planet Sci Lett 301: 469-478 